\title{
Impacts of the living wage on in-work poverty
}

Amy Horton, Department of Geography, University College London

Jane Wills, Department of Geography, University of Exeter

\section{Summary}

As low pay and in-work poverty have proliferated, demands for a higher, 'living wage', have gathered strength in countries such as the US and UK. Two decades since the first modern living wage campaign succeeded in Baltimore, a vibrant movement is challenging low pay across the US. In the UK, the government announced a 'national living wage' in 2015. This chapter reviews the efficacy of the living wage as a means of tackling in-work poverty. It begins by examining the extent to which low pay is a cause of household poverty, before explaining how living wages are calculated and briefly outlining the history of the movement. It then summarizes existing research on the impact of living wages on poverty and employment, as well the potential consequences of scaling up the living wage. The politics of the living wage are explored. The concept has served to mobilize broad coalitions of labour and community groups to challenge the marginalization of low-paid workers. However, the living wage also raises questions about where responsibility lies for tackling in-work poverty. Lastly, the chapter considers what future direction the living wage movement might take in order to make a greater impact on in-work poverty.

\section{Low pay and in-work poverty}

Since the 1980s, low pay has become more common in countries such as the UK and US, where more than a fifth of full-time employees now earn less than two-thirds of the median hourly wage (OECD 2015). The spread of low pay has been attributed to the loss of workers' bargaining power as rates of unionization have declined, labour markets been deregulated and jobs outsourced, as well as to the disappearance of semi-skilled, middle-income jobs (see Chapter 4). More recently, the focus of welfare policy on getting unemployed people into jobs and the global financial crisis have also contributed to more widespread low pay. Between 2009 and April 2013, the number of UK workers earning less than the living wage rose from 3.4 to 4.9 million (Lawton and Pennycook 2013; Corlett and Whittaker 2014).

Research shows that the minimum wage in the UK has served to raise pay for some 2 million workers and to reduce the gender wage gap (Metcalf 2007). However, the UK's minimum wage has been set 
too low to address in-work poverty (Marx and Nolan 2012:27). ${ }^{1}$ In the three years to 2014, the UK living wage was approximately 20 per cent higher, and the London rate 40 per cent higher, than the national minimum wage (Living Wage Foundation 2014b). The US federal minimum wage is some 25 per cent lower than that in the UK (at US $\$ 7.50$ and $£ 6.50$ or approximately $\$ 10$ per hour, respectively).

Whether an individual worker's low pay translates into household poverty depends on a range of factors including family size, working hours and household income from other workers and social security payments. Only around one in ten low-paid workers lives in a poor household in the UK (Maitre et al. 2012:107). However, low pay increases the risk of household poverty tenfold (Lawton and Pennycook 2013:36). Household poverty overlaps more with low pay in the UK than in many other European countries (Bennett 2013:56): almost half of those in poverty now live in households in which all adults are working (Maclnnes et al. 2014). Nearly two-thirds of children in poverty are in working households (Belfield et al. 2015).

\section{Defining a living wage}

Leading UK advocates describe the living wage as the hourly rate of pay required to provide workers and their dependents with a "basic but acceptable standard of living" (Citizens UK and Living Wage Foundation 2013:9). In London, municipal economists calculate a 'poverty threshold wage', which is based on 60 per cent of median income and a 'low cost but acceptable' budget, covering essential expenditures. These figures are weighted by the prevalence of different household forms and hours worked (GLA 2014). The living wage is also designed to facilitate "social integration and avoidance of chronic stress for earners and their dependents" (GLA 2014:9) and so a protective margin of 15\% is added. For the rest of the UK, since 2011, researchers have calculated a 'minimum income standard' based on public consultation (CRSP 2014), but capped relative to general changes in pay. Both figures are premised on full take-up of social security benefits. Across the US, a variety of municipal and state-level approaches have been adopted. A 'Living Wage Calculator' project also provides geographically-specific recommendations for a 'basic needs budget' and taxes; unlike the calculations in the UK, this does not include public income or housing assistance (MIT 2015). It is important to note that, without a very extensive 'social wage' or employee benefits, such as health services and childcare provision, the effectiveness of the living wage in ending in-work poverty will be highly uneven according to household circumstances. Single workers, and in particular single parents facing high childcare costs, require a higher income to exit poverty but in

\footnotetext{
${ }^{1}$ Net income from full-time work at the minimum wage rate was below the poverty threshold of 60 per cent of median incomes only in the UK and Spain, among western European countries.
} 
the UK are approximately twice as likely to be earning low wages (Hood et al. 2014:148). For example, MIT calculates that a living wage for a single adult in New York State is $\$ 12.75$ but $\$ 26.19$ for a single parent with one child (MIT 2015).

\section{Emergence and implementation}

The notion of a living wage emerged from the labour movement in Britain in the 1870s, and quickly spread to the United States (Glickman 1997; Wills and Linneker 2012). The idea gained support from some industrialists, suffragists and religious figures (Nield Chew 1894; Oldroyd 1894; Ryan 1906; Stapleford 2008). The movement contributed to the introduction of minimum wages in Britain and the US and influenced public contracting standards (Snowden 1912; Wills and Linneker 2012; Gordon 2014). Demands for the living wage faded after the Second World War in the context of collective bargaining, wage regulation and an expanding welfare state (Wills and Linneker 2012). However, from the 1960s, wage regulations were gradually abolished and the issue of low pay returned to public importance (Deakin and Green 2009; Wills 2009). In the US, the value of the minimum wage fell in real terms from the 1970s as successive governments refused to increase it on the grounds that jobs would be at risk (Gordon 2014). A national minimum wage was first introduced in the UK as late in 1999 (Deakin and Green 2009).

In the early 1990s, a new movement for the living wage began in Baltimore, Maryland. Churches providing social services observed the poverty of a growing number of working people and sought to address the issue through a broad-based network of community groups and a major public sector trade union. Their campaign evolved to demand that all city contractors pay a living wage - enough for a family of four to be above the federal poverty line (Walsh 2000; Fine 2006; Snarr 2011a). In the UK, the first modern campaign did not emerge until the next decade. The East London Communities Organisation, now part of Citizens UK, was concerned that low pay was causing financial problems, as well as forcing people to work long hours that cut into family time and community activities (Church Urban Fund and Church Action on Poverty 2011). Whereas US campaigns have tended to focus on public policy change, British organizations sought to pressure individual employers to adopt the living wage, and they secured their first breakthrough in 2004, signing agreements with Barclays Bank and HSBC.

Over the last two decades, well over 100 local living wage ordinances have been passed in the US (COWS 2013). They apply variously to public contractors and subsidy recipients (e.g. tax reductions, economic development incentives), or whole geographical areas. In the UK, by 2015 , the number of accredited living wage employers exceeded 1700, including many councils, universities, parts of the NHS, charities and private companies. In New Zealand, a campaign was launched in 2012 and has 
since accredited some 40 employers (Living Wage Movement Aotearoa New Zealand 2014). Australian trade unions also calculate a living wage periodically, though the country's relatively high minimum wage means that the rate is far less politically ambitious than in many other locations (Nordlund 1997). In Canada, the living wage is calculated at the level of states (Mackenzie and Stanford 2008).

There have also been efforts to move towards a living wage in global supply chains. Payment of the living wage, or action towards it, is mandated by a number of voluntary initiatives such as the Ethical Trading Initiative and Fairtrade (Ethical Trading Initiative 2014; Fairtrade International 2014). Since 2009, a coalition of labour and other groups have campaigned for the 'Asia Floor Wage', a nationallyadjusted rate of pay designed to halt the 'race to the bottom' in manufacturing. It has been taken up by some retailers, largely in the garment industry (Merk 2010; Wilshaw 2014).

\section{Poverty}

Relatively little research has examined the impacts of minimum and living wages on poverty, compared to their effects on employment (Reich et al. 2014). Researchers in the US have argued that living wage ordinances may overall produce modest reductions in poverty where they apply to all businesses receiving some form of public assistance, rather than only to public sector contractors (Neumark and Adams 2003). In 2013, Democrats proposed increasing the federal minimum wage from $\$ 7.25$ to $\$ 10.10$ per hour. Although considerably below the living wage in many places, it was estimated that the measure would reduce the number of people in poverty by an estimated 4.6 million, approximately a fifth of those in working poverty (Dube 2013; Reich et al. 2014). This reduction would be equivalent to almost a tenth of overall poverty among the non-elderly population (-1.7 percentage points from $17.5 \%$ baseline), with a greater impact over time (-2.5 percentage points) (Dube 2013:34). In the UK, analysis of the potential gains of raising the minimum wage towards a living wage concluded that most beneficiaries would be in the middle, rather than at the bottom, of the income distribution, since the poorest tend not to be working, while individuals on low pay live in households distributed across the income spectrum. However, as a proportion of income, poorer households would benefit more, because of progressive tax and benefits thresholds, and because the low-paying job is more likely to be their main source of earnings (Hood et al. 2014). Overall, raising the national minimum wage towards the living wage would raise the income of the poorest tenth of households by an estimated 12 per cent (Hood et al. 2014).

Even where employers adopt the hourly living wage, however, many workers' earnings will not be sufficient to avoid poverty. In a survey of approximately 200 workers receiving the London living wage, only a minority (38 per cent) reported financial benefits from its introduction. Those who had 
a second job - in which they were unlikely to be paid the living wage - were less likely to experience financial benefits (Wills and Linneker 2012; Linneker and Wills 2016). In part this is a reflection of workers being unable to work sufficient hours, either because of other responsibilities, such as childcare, or the unavailability of additional work at the living wage rate.

Voluntary or narrow application of the living wage is unlikely to have a significant direct impact on in-work poverty. However, wider 'spill over' effects may spread beyond those workers directly covered, as employers face greater competition in recruitment, wage norms move upwards, or employers choose to apply the living wage beyond those workers covered by living wage mandates (for example, to those not working on public contracts) (Devinatz 2013). Where employers also raise higher wages to maintain differentials, there may be an additional ripple effect among higher paid workers who may be in impoverished households (Chapman and Thompson 2006). Research on the living wage campaign conducted in the Lower Rio Grande Valley in Texas found that, of every 100 people receiving wage raises due to the implementation of a living wage ordinance, an additional 37 benefited from increased wages due to the ripple or spill-over effects (Osterman 2000). In the US, it has been suggested that a concentration of living wage laws in neighbouring cities may mean that they have greater impacts (Adams and Neumark 2005).

\section{Employment}

In debates about the introduction of a living wage, concerns have often been raised that the higher rate of pay could exacerbate poverty by negatively affecting employment or reducing funds available for non-wage employee benefits. Concerns have also centred on the risk of poor consumers facing higher prices for goods or services from living wage employers. A further risk for households facing poverty could come from the loss of cash transfers if state funds are redirected instead towards paying the living wage in the public sector or its contractors. However, research has found little evidence of such harmful impacts (Brenner 2005; Reich et al. 2005; Chapman and Thompson, 2006). In terms of the growth of employment, living wages appear to have no or small-scale negative effects (Buss and Romeo 2006; Lester 2011:252). A study of firms covered by a living wage law in Boston found that employment grew substantially after implementation (Brenner 2005). Research on minimum wage impacts, however, has found some evidence of small reductions in hours of work (Stewart \& Swaffield 2007; Reich et al. 2014).

In many cases, at least some of the costs of paying the living wage can be recouped by employers through higher productivity and savings from reduced staff turnover and absenteeism. Substantial minorities of affected firms in the US have reported improvements in employee performance, effort or morale. For example, after city contractors in Boston were required to pay a living wage from 
1999, a quarter of firms reported increased employee morale and effort (Brenner 2005:77). A largescale example of living wage roll-out occurred at San Francisco airport in 1999, affecting threequarters of non-managerial staff. In this case, as many as 45 per cent of employers said that their level of customer service improved after a living wage was introduced, while problems such as employee grievances, absenteeism and disciplinary issues also declined substantially (Reich et al. 2005:127). In Tucson, Arizona, 22 per cent of contractors reported improved productivity following the passage of a living wage ordinance in 1999 (Grant and Trautner 2004:74). In the UK, the benefits of adopting a living wage appear to have been more widespread: in early research, two-thirds of accredited living wage employers reported higher productivity and five out of six said that it had improved the quality of their staff (GLA Economics 2009).

Almost all studies have found reductions, often dramatic, in rates of employee turnover following living wage implementation, although in low-paying jobs requiring limited training, this typically only offsets a minority of the additional living wage costs (Brenner 2005; Fairris 2005; Howes 2005; Reich et al. 2005; Wills and Linneker 2012; Linneker and Wills 2016). Some employers have absorbed costs through lower margins (Brenner and Luce 2005; Wills and Linneker 2012; Linneker and Wills 2016). In many cases, public sector bodies have limited the impact on their budgets by requiring contractors to shoulder some of the higher wage costs, while also meeting specified levels of service quality or staffing (Chapman and Thompson 2006; Linneker and Wills 2016). These responses appear to be more common than passing on costs to consumers through higher prices (Brenner and Luce 2005). Overall, the costs to employers of living wage implementation have tended to be relatively small, equivalent to approximately 1-2 per cent of total operating costs (Pollin and Luce 1998; Chapman and Thompson 2006; Devinatz 2013). Where they are passed on to clients, the additional costs generally tend to be low compared to the total costs of the service (Reich et al. 2005).

However, there is some evidence that the introduction of the living wage can lead to the substitution of existing workers in ways that could entrench the poverty of groups that are least skilled or those that face discrimination. Where substitution has been detected by US case studies, it has been found that living wage jobs might be more likely to go to more highly trained or skilled workers (Adams and Neumark 2005; Reich et al. 2005; Fairris and Fernandez Bujanda 2008), men (Reich et al. 2005; Fairris and Fernandez Bujanda 2008), workers who have earned more previously, or particular ethnic groups (Fairris and Fernandez Bujanda 2008). The latter researchers estimated that more than a quarter of wage gains from Los Angeles' living wage ordinance were dissipated as existing workers were replaced. A UK study suggests that substitution of workers along racial and educational lines may be more acute here (Linneker and Wills 2016). These shifts likely reflect the impact of increased wage rates on labour supply (Akerlof and Yellen 1986; Arrowsmith et al. 2003; 
Manning 2003). Such dynamics illustrate the need for improved training for the least skilled, action to tackle discrimination, and the creation of more 'good jobs' to reduce competition for work.

The absence of significant effects on employment may reflect the limited application of the living wage (Freeman 2005). In the UK, the estimated 35,000 employees whose pay has risen as a result of the living wage are far outnumbered by the 5.2 million workers on low pay (Corlett and Whittaker 2014; Wills 2014). In the major low-paying sectors, such as retail and hospitality - which together account for a third of low pay (Hood et al. 2014) - living wage jobs remain exceptional. Voluntary uptake has overwhelmingly been by employers with a small proportion of low-paid workers: only around one in ten employees in accredited workplaces are paid the living wage as opposed to a higher rate (authors' calculations using Living Wage Foundation data). In the US, it is estimated that in most cases, living wage laws only affect 2-3 percent of the lowest tenth of earners (Holzer 2008:2).

\section{Scaling up the living wage}

There is an increasingly lively policy debate about the costs and benefits of scaling up the living wage, fuelled by widening implementation and the growing movement. For example, in the UK, some local government bodies require payment of the living wage by contractors of services including social care. A small number of retailers, such as Ikea, have become accredited living wage employers. In mid-2015, the UK government announced the phased implementation a 'national living wage', which although lower than the independently calculated rates, will see a universal uprating of the minimum wage towards 60 per cent of median earnings by 2020. In the US, campaigns for a significantly higher minimum wage have succeeded in numerous places and some sectors. The most visible mobilization has been the 'Fight for \$15' movement, which emerged from New York fast food workers in 2011 to become a national campaign backed by the Service Employees International Union. Although the \$15 target hourly wage rate has not been calculated as a living wage, it represents a significant increase, and is more than double the federal minimum wage for the US. In 2014, Seattle and San Francisco adopted a \$15 hourly minimum wage, and in 2015, the New York state wage board recommended that fast food workers be paid at least $\$ 15$ per hour (Office of Labor Standards Enforcement - City and County of San Francisco 2014; Seattle Office of the Mayor 2014; Zerba and McGeehan 2015).

Links between local groups calling for the living wage have been strengthening, not only across the US in the Fight for $\$ 15$, but also more widely. Luce (2011) called for more international solidarity between campaigners to scale up the living wage, and there are signs that it is developing rapidly. For example, in 2015, a delegation of US trade unionists from the fast food industry visited the UK, 
France, Argentina, Brazil, Japan, Denmark and the Philippines to help build a global alliance, which coordinated a day of action in 33 countries (Neate 2014). Advocates have also sought to expand the geographical scope of the living wage through regional or 'zonal' approaches (Pastor 2001; Wills 2008a), which aim to create a 'cluster' of better paid jobs that will set new standards of work (Ciscel 2000). Some campaigns have strategically targeted strategically multinational firms that employ large numbers of workers on low wages, such as major cleaning companies (Wills 2008b).

Various analysts have attempted to quantify the impacts of a mandatory living wage, although not directly on poverty. In 2014, the independent Living Wage Commission in the UK recommended that the government help to scale up the living wage by promoting it to employers and ensuring that all directly employed public sector workers received the rate, but stopped short of calling for a statutory living wage because of concerns about impacts on low-paying sectors and small and medium enterprises (Living Wage Commission 2014). One study estimated that introducing a statutory living wage at the independently calculated rates could reduce employment by 0.5 percentage points in the UK, but the authors caution that this does not represent a prediction since it does not take into account mitigating factors such as increased productivity or wage-led demand (Riley 2013). Other research, which attempted to account for these factors, suggested that a universal living wage could lead to a net gain in employment, with some low-wage sectors shrinking but others more than compensating (Reed 2013). In this way, the living wage could serve to shift the balance of employment away from low-paying industries such as retail and hospitality, in which paying the living wage would increase the wage bill by between 4.7 and 6.2 per cent respectively (Pennycook 2012:32). Evidence from the UK minimum wage, introduced in 1999, suggests that it has had little net impact on employment, in part thanks to higher wages making it easier to fill job vacancies (Metcalf 2007). However, in the US, it has been observed that, although $\$ 15$ per hour is below a living wage in many large cities, it exceeds the median wage in eight states, where employment effects would likely be significant (Rampell 2015). Such variations indicate the importance of setting rates that reflect local economic conditions, but arguably it is the common goal that has lent the Fight for $\$ 15$ much of its momentum.

Implementation of a national living wage could generate an overall increase in public resources, which could be used to tackle poverty. Several studies based on the independently calculated UK living wage rates predict a significant net gain in public revenue thanks to increased taxation and social security contributions, and reduced benefit and tax credit payments. ${ }^{2}$ Estimates of savings have varied between $£ 1.9$ billion and $£ 3.6$ billion (Lawton and Pennycook 2013; KPMG 2015). There

\footnotetext{
${ }^{2}$ Estimates range between $£ 1.9$ billion (KPMG 2015:7) and £3.6bn (Lawton and Pennycook 2013:5).
} 
may be additional savings from improved employee health and wellbeing, which was found to be higher in among workers for London Living Wage employers than in comparator companies (Flint et al. 2014). However, an independent government body estimates that the (lower) 'national living wage' to be implemented in the UK by 2020 could lead to an increase in unemployment of 0.2 percentage points, equivalent to 60,000 jobs, and a smaller - though still significant - net gain in public revenues than that forecast by previous studies (Office for Budget Responsibility 2015).

\section{Political gains}

While the direct effects of the living wage on in-work poverty have so far been modest, the movement has had a significant political impact: "at a time when powerful forces are bearing down on wages at the bottom end of the labour market, living wages are a rare example of countervailing pressure; a rallying cry against low pay that has harnessed the power of social norms to reframe perspectives and deliver tangible gains for thousands of low-paid workers" (Lawton and Pennycook 2013:4). Campaigns for the living wage have contributed to greater debate about in-work poverty, the costs of low pay to wider society, and economic inequality.

Indeed, the geography of living wage implementation to date indicates that it should be understood primarily as a political phenomenon rather than corresponding directly to patterns of low pay and inwork poverty. US research has indicated that living wage laws are more likely to be passed in places with high rates of poverty (Martin 2006), but also that their geography is heavily influenced by local political conditions, such as higher rates of liberal voting or unionization, or the presence of community-based organizations and wider alliances (Martin 2001; Swarts and Vasi 2011). In the UK, 60 per cent of workers who have benefited from a living wage pay increase were based in London (Wills 2014), despite the higher incidence of low pay in other regions (although the disparity is less striking when considering local living wage rates that reflect the higher cost of living in the capital) (Corlett and Whittaker 2014). People living in the north of England, Wales or Northern Ireland, are approximately 1.5 times as likely to have low hourly pay as those in the south east of England (Hood et al. 2014). In part this geography of the living wage may reflect employers' recognition of the higher cost of living in London (Bennett and Lister 2010) or the presence of large employers with relatively few low-paid workers, for whom the living wage is an affordable means of improving their business reputation. But it is also likely the result of the concentration of campaigning in the capital, reflected in the establishment of the process for calculating the London living wage by municipal economists in 2005 , whereas a standard rate for the rest of the country has only been set since 2011. 
Policy analysts have observed that, rather than focusing on wages, in-work poverty may be more effectively tackled by the state or employers providing targeted support to households with greater needs, for example through family tax credits or childcare provision (Bennett 2013; Dube 2013); they have further argued that the stigmatization of 'dependence' on such support should be challenged. However, in many cases the living wage calculation takes these other sources of income into account. Low pay is thus understood as, in many cases, contingent on employers' decisions, not simply an economic inevitability accurately reflecting the low value of particular workers' labour. For example, Louise Marie Rantzau, a Danish fast food worker who in 2014 travelled to New York to take part in solidarity action, wrote, "I work for McDonald's in Denmark, where an agreement between our union and the company guarantees that workers older than 18 are paid at least \$21 an hour. Employees younger than 18 make at least $\$ 15$ - meaning teenagers working at McDonald's in Denmark make more than two times what many adults in America earn working at the Golden Arches. To anyone who says that fast-food jobs can't be good jobs, I would answer that mine isn't bad" (Rantzau 2014). For many workers and their allies, this is a matter of justice and respect. In New York, the fast food activists demonstrated with placards quoting Mahatma Gandhi: "Poverty is the worst form of violence." The importance of such an approach is supported by empirical studies showing that low earners' preference is to raise their incomes through higher earnings, rather than in-work benefits, which research suggests do not alleviate their sense of being undervalued (Dean and Mitchell 2011; Lawton and Pennycook 2013). Such considerations may help to explain why workers employed by living wage employers have been found to have significantly higher levels of psychological wellbeing than those in non-living wage workplaces (Flint et al. 2014)

The simplicity and resonance of the living wage concept has mobilized broad alliances of labour, faith and community organizations (Nissen 2000). Broad-based alliances for the living wage have facilitated gains for workers where traditional union tactics have been undermined by factors such as high labour turnover and the loss of a meaningful bargaining partner through sub-contracting. Groups of unconventional allies have been able to use their profile to gain media attention and apply pressure to the 'ultimate employers' of sub-contracted workers, for example, a university or bank whose buildings were cleaned by people paid less than the living wage (Holgate and Wills 2007; Wills 2008b). In some cases, campaigners have highlighted the apparent clash between the core purposes of the main employer and the wage rates and conditions being offered to the sub-contracted workers on site. As an example, during 2004, the campaign at the Homerton Hospital in east London exposed the fact that domestic cleaning staff were not given paid sick leave and tended to come into work when unwell. This increased the risk of disease spreading to already sick patients in the hospital, undermining the core goals of the hospital trust (Wills, 2008b). The participation of faith 
groups in particular has lent many campaigns moral urgency that has contributed to their success (Wills et al. 2009; Snarr 2011b). Some campaigns have also created alliances between different groups of workers, bridging divides in skill, class and ethnicity that can often undermine unity at work (Brenner and Luce 2005).

The living wage movement has helped to raise public awareness of low wages and in-work poverty, and reframed the issues as questions of justice that are relevant to wider society (Reynolds 2001; Brenner and Luce 2005; Wills 2008a). By pointing out how low wages force workers to seek long hours, and so reduce the time they can spend with their families or engage in community activities, campaigners have presented the living wage as positive for the social fabric. For instance, the vicechair in the early days of the London living wage campaign, Deborah Littman, described how "People from faith, community and labour organisations came together to ask what was happening to their families ... they had less time to spend with their families, churches and community centres were empty, and people were struggling to make ends meet. Low pay was identified as the cause for all these different problems" (Church Urban Fund and Church Action on Poverty, 2011). This discourse could be seen as reflecting a multi-dimensional understanding of poverty that takes into account non-economic factors such as citizenship, social exclusion and emotions like shame.

The living wage has often provided a useful concept for generating sympathy among the wider public towards low-paid workers, helping to challenge their marginalization (Pastor 2001, Brenner and Luce 2005). In the UK, calls for the living wage have attracted broad support from the general public, the major political parties and trade unions (Eaton 2013; Reed 2013). Although many campaigns have been narrowly focused on the living wage and not necessarily addressed wider causes of in-work poverty (Reynolds 2001; Luce 2011), the movement as a whole has catalyzed a shift in political discourse around low pay (Reynolds 2001; Levin-Waldman 2005; Wills 2009). It has achieved significant policy impacts, evident in the UK government's announcement in 2015 of a national living wage; the accreditation of all local councils in Scotland as living wage employers and a significant proportion of those in England (GMB 2013); and planned increases in the minimum wage in approximately half of all US states (Economic Policy Institute 2015). Strategic and broad-based action by living wage advocates appears to be crucial in maximizing the impact of living wage campaigns. For example, in Los Angeles, the living wage ordinance was one piece in a series of legislation passed on labour rights, backed by over 100 organizations with significant mobilization of workers and the public. It helped to produce a new faith-based support network for workers, Clergy and Laity United for Economic Justice, and a 'social movement organization' to conduct research and organizing, the Los Angeles Alliance for a New Economy (Pastor, 2001). 
In some cases, living wage campaigns have facilitated the unionization of low-paid workers, representing small-scale reversals of a key cause of growing pay disparities. Provisions protecting the right to organize have been included in living wage ordinances in places including Santa Cruz, Los Angeles and Berkeley, California (Luce 2005:425). Some living wage mobilizations have served to build workers' confidence and willingness to be active in unions (Luce 2004; Sokol et al. 2006; Wills 2008a), as well as challenging negative perceptions of unions as defenders of special interests (Luce 2004). For example, living wage campaigns have been accompanied by successful unionization efforts in Chicago, Berkeley and San Jose (California), and Tucson, Arizona (Luce 2004). A number of campaigns have also provided an experimentation ground for organizing workers in geographically dispersed and often temporary jobs. For example, in Baltimore, workers were able to join the Solidarity Sponsoring Committee, where membership was not linked to a particular workplace, and this organization went on to play an active role in enforcing the living wage (Walsh 2000; Fine 2006). Although only a minority of campaigns have been worker-led or accompanied by large-scale unionization, these examples indicate that the living wage can serve as a platform for organizing workers and their allies around a wider set of demands.

\section{Political risks}

However, it is important to recognize that the concept of the living wage also carries political risks that could ultimately reinforce in-work poverty. In many cases, the living wage has been applied in a 'top-down' manner without the involvement of organized workers (Reynolds 2001). Although this can still help to raise pay for marginalized workers who have struggled to unionize or assert their claims, adoption of the living wage in this way may be geared towards benefiting the employer's reputation while doing little to shift the balance of power. Where the living wage is implemented without organizing labour, enforcement of its payment may be weak (Fairris and Reich 2005). Such an approach also risks leaving workers with little capacity to resist employer efforts to recoup costs by intensifying work or cutting other costs such as hours and benefits (Linneker and Wills 2016). In global supply chains, there is a risk of employers capturing higher payments made by downstream firms that are intended to fund higher wages. Indeed where few other living wage jobs are available, employees may become further dependent on their employer. Furthermore, applying a general, technical wage calculation does not help to build workers' capacity to negotiate wage rates that respond to particular local or workforce conditions. As occurred with the minimum wage, the living wage may become a wage 'ceiling' rather than 'floor'; in the UK, as many as 7 per cent of workers are expected to earn the 'national living wage' by 2020 , according to official forecasts (D'Arcy and Kelly 2015). Historically, some trade unions have therefore opposed the living wage and some 
current institutions aiming to raise wages, such as the Ethical Trading Initiative (Bennett and Lister 2010) also prefer an approach based on collective bargaining.

The living wage is often presented as enabling workers and their families to live independently of state support, although some living wage calculations, such as those in the UK do assume full takeup of benefit entitlements (Bennett 2013). This may be an attractive prospect given the vulnerability of such payments to changes of government policy and their exclusion of many low earners who are non-citizens. However, it also suggests that responsibility for avoiding poverty lies with individual earners and their employers via the wage relation, rather than the state or other collective actors. This risks undermining political support for social security and services that can respond to particular household needs - for example those including children or people with disabilities - in ways that wages cannot, and it therefore tends to leave a significant residue of in-work poverty (Bennett and Lister 2010). Similarly, rather than calling on employers to reallocate resources to higher pay, demands could focus on more targeted support, such as better pay for parental leave (Bennett and Lister 2010). The absence of such provision is likely to have particularly severe impacts for women given the unequal distribution of low pay and caring responsibilities (Bennett 2013). Indeed, the shift towards a 'national living wage' in the UK is being accompanied by cuts to tax credits for low-income workers and families with children, which overall will leave many households worse off (D'Arcy and Kelly 2015). Employers are also being compensated by reduced corporation tax rates and social security contributions, as part of a project to reduce the redistributive role of the state.

Furthermore, unless integrated carefully with tax and benefit systems, high rates of effective marginal tax or sharp benefit withdrawal thresholds may also limit the benefits of higher wages for low earners.

\section{Where next for the living wage?}

Although the living wage focuses on low pay, the movement's politicization of earnings has highlighted the imbalance of power that has contributed to the expansion of in-work poverty in certain countries, at the same time as top earnings have risen sharply (Piketty 2014). High pay has been understood as contributing to in-work poverty by generating demand for low-paying services and for assets such as property, which may push up the cost of living (Sassen 1991; Wills et al; 2010; Green and Shaheen 2014). The political influence of high earners on wage regulations and norms may also play a part (Hacker and Pierson 2011). The living wage may therefore provide a foundation for tackling inequalities. Indeed, when the minimum wage was first introduced in the US in 1938 following demands for a wage floor, it was part of the New Deal, which targeted not only low pay, but also upper extremes. The minimum wage was accompanied by high taxes on large incomes, disclosure requirements for executive salaries in large corporations, and refusal of public finance and 
contracts to companies deemed to be paying excessive wages to senior employees (Washington 1941).

Low pay and in-work poverty disproportionately affect particular groups, and while the living wage can benefit them directly, it may not address the underlying causes of their economic marginality. Critics of the living wage concept have argued that it fails to challenge the under-valuing of female or ethnic minority workers, or forms of labour such as care (Bennett 2013). In the UK, women are much more likely than men to be paid less than the living wage (27\% compared to $16 \%$ ) (Living Wage Foundation 2014a); this disparity is high by international standards and persists even controlling for characteristics such as education and age (Lawton and Pennycook 2013; Hood et al. 2014). In addition, part-time workers, who are far more likely to be women, suffer a higher pay penalty in the UK than do their counterparts in other advanced economies (Manning and Petrongolo 2004). They are more than three times as likely to be on low pay compared to those working full time ( $43 \%$ compared to $13 \%$ ) (Corlett and Whittaker 2014). In London, only $13 \%$ of full-time employees in London earn less than the London Living Wage, but a majority (51.2\%) of part-time workers do and more than a third of them earn below the poverty threshold wage (38\%) (GLA 2014). Particular ethnic groups also experience high rates of low pay, partly as a result of discrimination and/or labour market segmentation; Bangladeshi and Pakistani workers in the UK, for example, are 1.6 times as likely to earn low hourly wages as those of white ethnicity (Hood et al. 2014). Young people in the UK are also far more likely than older workers to be on low pay. While this partly reflects lesser skills and experience, it is also reinforced by policies mandating lower minimum wages: the current minimum wage rate for 18-21 year olds is more than 25 per cent less than the standard rate and the 'national living wage' will not apply to under-25s. As welfare retrenchment also excludes young people - for example, in mid-2015 under-21s lost their automatic entitlement to housing benefit they will become more vulnerable to in-work poverty. Additional political mobilizations and policy interventions are required to tackle these issues.

Some living wage campaigns appear to be building on their successes to address a wider agenda in ways that could magnify their impact on in-work poverty. For example, activists in the US have been seeking to combine their demands for higher pay with broader demands over issues such as inequality and the cost of childcare. As one Fight for $\$ 15$ activist puts it: "Things are starting to change - winning \$15/hour in L.A. and for fast-food workers in New York State - but here's the truth about child care: even with more pay, working parents can barely afford child care and the people who provide child care can't survive on their low pay. [...] We expect skilled teachers to set up our kids for lifelong learning and success, yet those workers are paid a median wage of $\$ 9.38$ per hour. That's a whole lot less than, say, the guy who writes the jingle for a soap commercial or the woman 
turning the letters on the game show. [...] We need to increase funding for child care to ease the burden on moms like me and to make sure that the people taking care of my kids earn a living wage" (campaign email, July 2015). As well as highlighting economic and gender dynamics, living wage movements have addressed their intersection with racial inequalities. As an example, activists organizing against police brutality in the 'Black Lives Matter' movement have played a prominent role in the Fight for $\$ 15$.

Campaigns for a living wage have also been growing in relation to the direct care sector, such as Citizens UK's campaign called "I care about care". They have emphasized how low pay and in-work poverty affect this huge, largely female and ethnic minority workforce. Addressing low pay as well as the under-valuation of care represents a major challenge to those seeking to curb in-work poverty. To avoid serious deteriorations in service quality, the UK's 'national living wage' will demand either major reductions in services or major change in this sector. Already minimum wage violations are common and nearly a million workers are estimated to earn below the current independently calculated living wage rate; the primary funding source - local government - has been cut substantially by ongoing austerity programmes, while demand is rising with an ageing population (Pennycock 2013; D'Arcy and Kelly 2015). Although sector-specific changes to funding and career progression are crucial, remedying the under-valuing of care will also require shifting fundamental cultural and economic norms.

\section{Conclusion}

Although low hourly pay for an individual does not translate straightforwardly into poverty at the household level, low pay significantly increases the risk of in-work poverty. In the UK, poverty has shifted dramatically from the unemployed and pensioners to working households, which now include nearly half of all those living in poverty. In this context, raising the wage floor beyond the low national minimums found in the US and UK towards a level that better reflects the cost of living can help to lift households out of poverty. Experience suggests that paying a living wage need not lead to greater unemployment, thanks to higher productivity, reduced staff turnover and employers' adaptations. There is, though, some evidence that the living wage can lead to the displacement of the most disadvantaged workers from their jobs. Additional efforts are needed to improve their skills and tackle barriers such as discrimination. Scaled up, the capacity of higher wages to stimulate consumer demand and boost state finances means that the living wage is expected to reduce poverty without major negative impacts. Politically, the concept of the living wage has inspired labour organizing, broad coalitions and public sympathy that have helped to tilt power in favour of marginalized workers. 
However, unless the living wage is situated within a broader approach of collective provision for households with greater needs, simply raising wages risks leaving those households exposed to poverty. They must be supported by government and employer policies, such as subsidized childcare provision and paid parental leave. The living wage also needs to be articulated with other action to address low pay and in-work poverty, including strengthening workers' bargaining power, for example through unionization, and greater job security, since low pay is more common in short-term jobs (Hood et al. 2014).

Amy Horton would like to acknowledge the support of the Economic and Social Research Council for her doctoral research work through grant number ES/J500124/1. Jane Wills was funded by Trust for London to lead a research project to explore the costs and benefits of the London living wage between 2010 and 2013.

\section{Bibliography}

Adams, S. and Neumark, D., 2005. Living Wage Effects: New and Improved Evidence. Economic Development Quarterly, 19(1), pp.80-102.

Akerlof, G. and Yellen, J., 1986. Efficiency Wage Models of the Labor Market, Cambridge: Cambridge University Press.

Arrowsmith, J. et al., 2003. The Impact of the National Minimum Wage in Small Firms. British Journal of Industrial Relations, 41(3), pp.435-456.

Belfield, C. et al., 2015. Living standards, poverty and inequality in the UK: 2015, London: Institute for Fiscal Studies.

Bennett, F., 2013. The "living wage", low pay and in work poverty: Rethinking the relationships. Critical Social Policy, 34(1), pp.46-65.

Bennett, F. and Lister, R., 2010. The "Living Wage": The right answer to low pay?, London: Fabian Society.

Brenner, M., 2005. The Economic Impact of the Boston Living Wage Ordinance. Industrial Relations, 44(1), pp.59-83.

Brenner, M. and Luce, S., 2005. Living Wage Laws in Practice: The Boston, New Haven and Hartford Experiences, Amherst, MA: PERI.

Buss, J. and Romeo, A., 2006. The Changing Employment Situation in Some Cities with Living Wage Ordinances. Review of Social Economy, 64(3), pp.349-367.

Chapman, J. and Thompson, J., 2006. The economic impact of local living wages, Washington, DC: Economic Policy Institute. 
Church Urban Fund and Church Action on Poverty, 2011. The Living Wage and the Role of the Church, London: Church Urban Fund and Church Action on Poverty.

Ciscel, D., 2000. The Living Wage Movement: Building a Political Link from Market Wages to Social Institutions. Journal of Economic Issues, 34(2), pp.527-535.

Citizens UK and Living Wage Foundation, 2013. Recommendations for Living Wage Leadership, London: Citizens UK and the Living Wage Foundation.

Corlett, A. and Whittaker, M., 2014. Low Pay Britain 2014, London: Resolution Foundation.

COWS, 2013. Local Living Wage Ordinances: Experience, Evidence and Best Practice, Madison, WI: cows.

CRSP, 2014. Uprating the UK Living Wage in 2014, Loughborough: Centre for Research in Social Policy, Loughborourgh University.

D'Arcy, C. and Kelly, G., 2015. Analysing the National Living Wage: Impact and implications for Britain's low pay challenge, London: Resolution Foundation.

Deakin, S. and Green, F., 2009. A century of minimum wages in Britain. Centre Piece, Autumn, pp.68.

Dean, H. and Mitchell, G., 2011. Wage top-ups and work incentives: The implications of the UK's Working Tax Credit scheme, London: LSE.

Devinatz, V.G., 2013. The Significance of the Living Wage for US Workers in the Early Twenty-First Century. Employee Responsibilities and Rights Journal, 25(2), pp.125-134.

Dube, A., 2013. Minimum Wages and the Distribution of Family Incomes (Working Paper), Amherst MA: University of Massachusetts Amherst and IZA.

Eaton, G., 2013. The public support a universal living wage - even if it costs jobs. New Statesman. 22 February.

Economic Policy Institute, 2015. Exploring EPI's Minimum Wage Tracker. Available at: http://www.epi.org/blog/exploring-epis-minimum-wage-tracker/ [Accessed August 1, 2015].

Ethical Trading Initiative, 2014. The ETI Base Code, London: ETI.

Fairris, D., 2005. The Impact of Living Wages on Employers: A Control Group Analysis of the Los Angeles Ordinance. Industrial Relations, 44(1), pp.84-105.

Fairris, D. and Fernandez Bujanda, L., 2008. The Dissipation of Minimum Wage Gains for Workers through Labor-Labor Substitution: Evidence from the Los Angeles Living Wage Ordinance. Southern Economic Journal, 75(2), pp.473-496.

Fairris, D. and Reich, M., 2005. The Impacts of Living Wage Policies: Introduction to the Special Issue. Industrial Relations, 44(1), pp.1-13.

Fairtrade International, 2014. Fairtrade Standard for Hired Labour, Bonn: Fairtrade International.

Fine, J., 2006. Worker Centers: Organising workers on the edge of the dream, Ithaca NY: Cornell University Press. 
Flint, E., Cummins, S. and Wills, J., 2014. Investigating the effect of the London living wage on the psychological wellbeing of low-wage service sector employees: a feasibility study. Journal of Public Health, 36(2), pp.187-93.

Freeman, R., 2005. Fighting for Other Folks' Wages: The Logic and Illogic of Living Wage Campaigns. Industrial Relations, 44(1), pp.14-31.

GLA, 2014. A Fairer London: The 2014 Living Wage in London, London: Greater London Authority.

GLA Economics, 2009. An Independent Study of the Business Benefits of Implementing a Living Wage Policy in London, London: GLA Economics.

Glickman, L., 1997. A Living Wage: American Workers and the Making of Consumer Society, London: Cornell University Press.

GMB, 2013. 82 Councils Pay Living Wage. Available at: http://www.gmb.org.uk/newsroom/councilspay-living-wage [Accessed August 7, 2015].

Gordon, C., 2014. Growing Apart: A Political History of American Inequality. Available at: http://scalar.usc.edu/works/growing-apart-a-political-history-of-american-inequality/index [Accessed August 1, 2015].

Grant, D. and Trautner, M.N., 2004. Employer Opinions on Living Wage Ordinances. WorkingUSA, 8(1), pp.71-82.

Green, B. and Shaheen, F., 2014. Economic inequality and house prices in the UK (Working Paper). London: New Economics Foundation.

Hacker, J. and Pierson, P., 2011. Winner-Take-All Politics: How Washington Made the Rich Richer-and Turned Its Back on the Middle Class. London: Simon and Schuster.

Holgate, J. and Wills, J., 2007. Organizing Labor in London: Lessons from the Campaign for the Living Wage. In L. Turner and B. Cornfield, eds. Labor in the New Urban Battlegrounds: Local Solidarity in a Global Economy. Ithaca: ILR Press, pp. 211-223.

Holzer, H., 2008. Living Wage Laws: How much do (can) they matter?, Washington DC: Metropolitan Policy Program, Brookings Institution.

Hood, A., Joyce, R. and Phillips, D., 2014. Policies to Help the Low Paid. In C. Emmerson, P. Johnson, and H. Miller, eds. IFS Green Budget 2014. London: Institute for Fiscal Studies, pp. 141-171.

Howes, C., 2005. Living Wages and Retention of Homecare Workers in San Francisco. Industrial Relations, 44(1), pp.139-163.

KPMG, 2015. The Living Wage: An economic impact assessment. London: KPMG.

Lawton, K. and Pennycook, M., 2013. Beyond the Bottom Line: The challenges and opportunities of a living wage, London: IPPR and Resolution Foundation.

Lester, T.W., 2011. The Impact of Living Wage Laws on Urban Economic Development Patterns and the Local Business Climate: Evidence from California Cities. Economic Development Quarterly, 25(3), pp.237-254.

Levin-Waldman, O.M., 2005. The Political Economy of the Living Wage: A Study of Four Cities, Armonk, NY: M.E. Sharpe. 
Linneker, B. \& Wills, J. (2016). The London living wage and in-work poverty reduction: Impacts on employers and workers. Environment and Planning C: Government and Policy. 34 (5). p.pp. 759-776.

Living Wage Commission, 2014. Work That Pays: The Final Report of the Living Wage Commission, London: Living Wage Commission.

Living Wage Foundation, 2014a. Living Wage and women in-work poverty. Available at:

http://www.livingwage.org.uk/news/living-wage-and-women-work-poverty [Accessed August 25, 2015].

Living Wage Foundation, 2014b. The Calculation. Available at:

http://www.livingwage.org.uk/calculation. [Access August 4, 2014].

Living Wage Movement Aotearoa New Zealand, 2014. Living Wage Movement. Available at: http://www.livingwage.org.nz/about [Accessed August 1, 2015].

Luce, S., 2004. Fighting for a Living Wage, Ithaca NY: Cornell University Press.

Luce, S., 2005. Lessons from Living-Wage Campaigns. Work and Occupations, 32(4), pp.423-440.

Luce, S., 2011. What next for the U.S. Living Wage Movement? Canadian Review of Social Policy, 6566, pp.128-138.

Maclnnes, T., Aldridge, H., Bushe, S., Tinson, A., Barry-Born, T., 2014. Monitoring Poverty and Social Exclusion 2014, York: Joseph Rowntree Foundation.

Mackenzie, H. and Stanford, J., 2008. A Living Wage for Toronto, Ottowa: Canadian Centre for Policy Alternatives.

Maitre, B., Nolan, B. and Whelan, C.T., 2012. Low Pay, In-Work Poverty and Economic Vulnerability: A comparative analysis using EU-SILC. The Manchester School, 80(1), pp.99-116.

Manning, A., 2003. Monopsony in Motion: Imperfect Competition in Labor Markets, Princeton NJ: Princeton University Press.

Manning, A. and Petrongolo, B., 2004. The part-time pay penalty, London: LSE.

Martin, I., 2001. Dawn of the Living Wage: The Diffusion of a Redistributive Municipal Policy. Urban Affairs Review, 36(4), pp.470-496.

Martin, I., 2006. Do Living Wage Policies Diffuse? Urban Affairs Review, 41(5), pp.710-719.

Marx, I. and Nolan, B., 2012. In-Work Poverty, Amsterdam Institute for Advanced Labour Studies: Amsterdam.

Merk, J., 2010. Cross-border wage struggles in the global garment industry: the campaign for an Asia floor wage, London: Routledge.

Metcalf, D., 2007. Why has the British national minimum wage had little or no impact on employment? (CEP Discussion Paper), London: Centre for Economic Performance, LSE.

MIT, 2015. Living Wage Calculator. Available at: http://livingwage.mit.edu/ [Accessed August 1, 2015].

Neate, R., 18 November 2014. UK fast-food workers get US lesson in protesting against poverty wages. The Guardian. 
Neumark, D. and Adams, S., 2003. Do Living Wage Ordinances Reduce Urban Poverty? Journal of Human Resources, XXXVIII(3), pp.490-521.

Nield Chew, A., 19 May 1894. A Living Wage for Factory Girls at Crewe. Chronicle.

Nissen, B., 2000. Living Wage Campaigns From a "Social Movement" Perspective: The Miami Case. Labor Studies Journal, 25(3), pp.29-50.

Nordlund, W.J., 1997. The quest for a living wage: The history of the federal minimum wage program, Westport CT: Greenwood Press.

OECD, 2015. Wage levels (indicator). Available at: https://data.oecd.org/earnwage/wage-levels.htm [Accessed August 25, 2015].

Office for Budget Responsibility, 2015. Economic and Fiscal Outlook, London: OBR.

Office of Labor Standards Enforcement - City and County of San Francisco, 2014. Minimum Wage

Ordinance. Available at: http://sfgsa.org/index.aspx?page=411 [Accessed August 25, 2015].

Oldroyd, M., 1894. A Living Wage, Leeds: McCorquodale and Co., Limited.

Osterman, P., 2000. Report on the Impact of the Valley Interfaith Living Wage Campaign, Cambridge MA: MIT Sloan School of Management.

Pastor, M., 2001. Common Ground at Ground Zero? The New Economy and the New Organizing in Los Angeles. Antipode, 33(2), pp.260-289.

Pennycook, M., 2012. What price a living wage? Understanding the impact of a living wage on firmlevel wage bill, London: Resolution Foundation.

Pennycock, M., 2013. Does it pay to care? Under-payment of the National Minimum Wage in the social care sector, London: Resolution Foundation.

Piketty, T. 2014. Capital in the Twenty-First Century. Cambridge MA: Harvard University Press.

Pollin, R. and Luce, S., 1998. The Living Wage: Building a Fair Economy, New York NY: New Press.

Rampell, C., 20 July 2015. The downside of doubling the federal minimum wage. The Washington Post.

Rantzau, L. 15 May 2014 I’m making \$21 an hour at McDonald's. Why aren't you? Reuters.

Reed, H., 2013. The Economic Impact of Extending the Living Wage to all Employees in the UK, London: Landman Economics.

Reich, M., Hall, P. and Jacobs, K., 2005. Living Wage Policies at the San Francisco Airport: Impacts on Workers and Businesses. Industrial Relations, 44(1), pp.106-138.

Reich, M., Jacobs, K. and Bernhardt, A., 2014. Local Minimum Wage Laws: Impacts on Workers, Families and Businesses (Working Paper), Berkeley, CA: Institute for Research on Labor and Employment, Berkeley.

Reynolds, D., 2001. Living Wage Campaigns as Social Movements: Experiences from Nine Cities. Labor Studies Journal, 26, pp.31-64. 
Riley, R., 2013. Modelling Demand for Low Skilled / Low Paid Labour: Exploring the employment trade-offs of a living wage, London: National Institute of Economic and Social Research and Centre for Learning and Life Chances in Knowledge Economies.

Ryan, J.A., 1906. A Living Wage: Its Ethical and Economic Aspects, New York: Macmillan.

Sassen, S., 1991. The Global City., Princeton NJ: Princeton University Press.

Seattle Office of the Mayor, 2014. \$15 Minimum Wage. Available at:

http://murray.seattle.gov/minimumwage/\#sthash.6dgWe7mO.dpbs [Accessed August 1, 2015].

Snarr, C., 2011a. All You That Labor: Religion and Ethics in the Living Wage Movement, New York NY: NYU Press.

Snarr, C.M., 2011b. Women's working poverty: Feminist and religious alliances in the living wage movement. Journal of Feminist Studies in Religion, 27(1), pp.75-93.

Snowden, P., 1912. The Living Wage, London: Hodder and Stoughton.

Sokol, M. et al., 2006. The impact of improved pay and conditions on low-paid urban workers: the case of the Royal London Hospital, London: Queen Mary University of London, London Citizens and UNISON.

Stapleford, T.A., 2008. Defining a "living wage" in America: Transformations in union wage theories, 1870-1930. Labor History, 49(1), pp.1-22.

Stewart, M. and Swaffield, J., 2007. The Other Margin: Do Minimum Wages Cause Working Hours Adjustments for Low-Wage Workers? Economica, 75(297), pp. 148-167.

Swarts, H. and Vasi, I.B., 2011. Which U.S. Cities Adopt Living Wage Ordinances? Predictors of Adoption of a New Labor Tactic, 1994-2006. Urban Affairs Review, 47(6), pp.743-774.

Walsh, J., 2000. Organizing the scale of labor regulation in the United States: Service-sector activism in the city. Environment and Planning A, 32(9), pp.1593-1610.

Washington, G., 1941. The Corporation Executive's Living Wage. Harvard Law Review, 54(5), pp.733774.

Wills, J., 2008a. Making Class Politics Possible: Organizing Contract Cleaners in London. International Journal of Urban and Regional Research, 32(2), pp.305-323.

Wills, J., 2008b. Subcontracted Employment and its Challenge to Labor. Labor Studies Journal, 34(4), pp.441-460.

Wills, J., 2009. The living wage. Soundings: A journal of politics and culture, 42, pp.33-46.

Wills, J., 2014. The impact of the national Living Wage Foundation. Available at:

http://www.geog.qmul.ac.uk/livingwage/national/index.html.

Wills, J. Datta, K. Evans, Y. Herbert, J. May, J. and Mcllwaine, C. 2009. Religion at work: The role of faith-based organizations in the London living wage campaign. Cambridge Journal of Regions, Economy and Society, 2(3), pp.443-461.

Wills, J. and Linneker, B., 2012. The costs and benefits of the London living wage, London: Trust for London and Queen Mary University of London. 
Wills, J., May, J., Datta, K., Evans, Y., Herbert, J. and Mcllwaine, C. 2010 Global Cities At Work: New Migrant Divisions of Labour. London: Pluto Press.

Wilshaw, R., 2014. Steps Towards a Living Wage in Global Supply Chains, Oxford: Oxfam.

Zerba, A. and McGeehan, P., 23 July 2015. A Guide to New York's \$15 Minimum Wage Proposal. The New York Times. 